
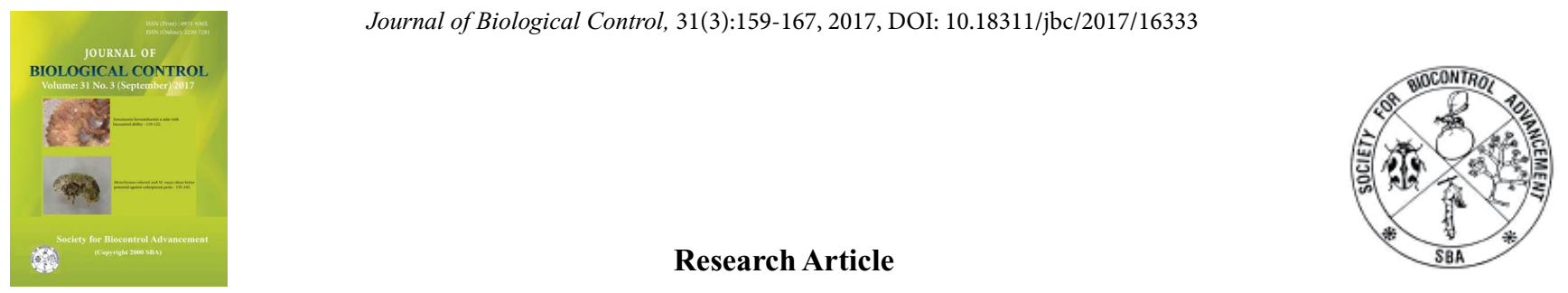

\title{
Detection of insecticide resistance and mechanisms of resistance in field populations of Chrysoperla zastrowi sillemi (Neuroptera: Chrysopidae) collected from different geographical locations in India
}

\author{
T. VENKATESAN ${ }^{*}$, S. HELEN MAHIBA ${ }^{2}$, S. K. JALALI ${ }^{1}$, S. L. RAMYA ${ }^{1}$ and M. PRATIBHA ${ }^{1}$ \\ ${ }^{1}$ ICAR-National Bureau of Agricultural Insect Resources, P.B. No. 2491, H.A. Farm Post, Hebbal, Banaglore - 560024, \\ Karnataka, India \\ ${ }^{2}$ Regional Seri cultural Research Station Central Silk Board, Veeranam Road, Allikuttai Post, Vaikkalapattarai, \\ Salem - 636003, Tamil Nadu, India \\ ${ }^{*}$ Corresponding author E-mail: tvenkat12@gmail.com
}

\begin{abstract}
The toxic effect of commonly used insecticides in cotton fields was studied on 9 populations of Chrysoperla zastrowi sillemi (Esben-Petersen), an important predator of sucking pests collected in India. The dose mortality bioassay against 3-days old larvae was determined using three insecticides viz., endosulfan, fenvalerate and acephate by topical bioassay method. Mechanism of resistance to the above mentioned insecticides were determined without and with three metabolic inhibitors (synergists), viz., piperonyl butoxide (PBO), S,S,S-tributyl-phosphorotrithioate (DEF) and diethyl maleate (DEM). Among the populations, resistant ratios (RR) of CZS-8 was significantly higher i.e. 50.36., 66.11 and 277.51-fold for endosulfan, fenvalerate and acephate, respectively compared to susceptible population (CZS-10). The CZS-8 was selected for synergism study it showed higher $\mathrm{LC}_{50}$ values and resistance ratio for all three insecticides. It showed 8.97-fold, 18.49-fold and 6.38-fold increase in synergism ratio for endosulfan indicating the resistance was strongly synergised by PBO, DEF and DEM. Similarly for fenvalerate, CZS-8 showed 8.69-fold and 3.63-fold significant increase in synergism ratio by DEF and DEM, respectively and for acephate, CZS-8 showed 54.82-fold, 150.87-fold and 113.52-fold significant increase in synergism ratio indicating that the resistance could be due to cytochrome p-450, esterase and glutathione s- transferase activity. The study indicated that the field population of C. z. sillemi developed resistance to different groups of insecticides. Among different geographical populations, CZS-8 collected from Sriganganagar, was recorded as most resistant.
\end{abstract}

KEY WORDS: Chrysoperla zastrowi sillemi, cytochrome p450, esterase, glutathione -S- transferase insecticide resistance,

(Article chronicle: Received: 22-06-2017; Revised: 21-09-2017; Accepted: 30-09-2017)

\section{INTRODUCTION}

The Common green lacewing, Chrysoperla zastrowi sillemi (Esben-Petersen) (Neuroptera: Chrysopidae), is an important biological control agent of sucking pests in different agroecosystems (Symondron et al., 2002; Venkatesan et al., 2008; Henry et al., 2010). It has long been considered as a promising candidate for pest management programs worldwide due to its wide prey range and geographical distribution, voracious larval feeding capacity and commercial availability (Medina et al., 2003; Pathan et al., 2010; Sayyed et al., 2010). Parasitoids and predators are highly susceptible to insecticides than their host insects [Croft and Brown, 1975), which make them difficult to establish in insecticide sprayed field. Parasitoids and predators are known to develop resistance to insecticides in nature like their prey insects either by direct exposure or by consumption of prey insects treated with insecticides (Wu et al., 2004; Wu and
Miyata, 2005). However, resistance development is due to a combination of biological and ecological factors operating in the field (Venkatesan et al., 2009; Pathan et al., 2010). Compatibility of insecticide with biocontrol agents is important as their application against the insect pests directly and indirectly determines the effectiveness of bioagents. In nature, populations of predators and insect pests always mutually co-exist often in a density-dependant association. Any adaptation of the insect pests with insecticide sprays is likely to be followed by the predator also to sustain themselves in a given habitat.

In India, several chemical insecticides are used indiscriminately to control insect pests especially on cotton against sucking pests, which has led to resistance in many insect pests (Reddy and Rao, 1989; Kranthi et al., 2001). In a study conducted from 2007 to 2009, monocrotophos 
resistance was documented in field populations of C. zastrowi sillemi (Venkatesan et al., 2009). Chrysopid predators have been found resistant to insecticides in USA (Grafton and Hoy, 1985), Pakistan (Pathan et al., 2008; Sayyed et al., 2010), India (Venkatesan et al., 2009) \& Canada (Pree et al., 2009). In a study, significantly higher fitness attributes viz., intrinsic rate, survival rate, doubling time and predation rate has been reported in organophosphate and pyrethroid resistant populations of $C$. carnea (Pathan et al., 2008) contrary to general belief of genetic trade-off in such attributes in insects. However, information about the resistance level for different groups of insecticides and the mechanism(s) of resistance is important for successful augmentative releases of the resistant strain especially in the IPM of insect pests. Therefore, release of insecticide resistant predators would improve their survival in sprayed situations for potential use in augmentative biological control or integrated pest management strategies in many crops. Further, such predators can play an effective role in delaying the development of resistance in pest populations and reduce the pest resurgence.

Metabolic enzymes play a significant role in detoxification of insecticides in insects (Motoyama, 1980). Mixed function oxidase, glutathione-s-transferase and esterase are involved in many insects in insecticide resistance mechanisms (Narahashi et al., 1995) due to their ability to detoxify insecticides and other xenobiotics (Li et al., 2007). Many synergists such as piperonyl butoxide (PBO), diethyl maleate (DEM) and S,S,S-tributyl phosphoro trithioate (DEF) used at non-toxic doses are known to inhibit monoxygenase, glutathione-s-transferase and esterase activities, respectively (Casida, 1970; Scott, 1990). However, work on insecticide resistance and mechanisms of resistance in chrysopid predators is very scanty and this is first kind of such study in India. Therefore, in the present study, based on the initial screening to representatives of three major groups of insecticides, namely endosulfan (cyclodiene), fenvalerate (synthetic pyrethroid) and acephate (organophosphate), a resistant strain of C. $z$. sillemi (CZS-8) was selected and effect of synergists (PBO, DEM \& DEF), known to inhibit important detoxification routes, was investigated to know the mechanisms of resistance in the resistant population of C. z. sillemi. Thus the study focuses on selection of an insecticide resistant predator C. z. sillemi which can be used as one of the important components in the pest management strategies especially under insecticide stressed crop conditions.

\section{MATERIALS AND METHODS}

\section{Chrysoperla zastrowi sillemi populations}

Nine populations of Chrysoperla z. sillemi ( 100 larvae/adults) were collected in 2008-09 from heavily sprayed cotton fields in 9 cotton growing districts in eight states, viz., Coimbatore (Tamil Nadu state) Anand (Gujarat state), Delhi state, Sirsa (Haryana state), Sriganganagar \& Udaipur (Rajasthan state), Guntur (Andhra Pradesh state), Dharward (Karnataka state) and Ludhiana (Punjab state). The pesticide use pattern was recorded from each collection site (Table 1). A laboratory population of C. z. sillemi originally maintained for the past 11 years at ICAR-National Bureau of Agricultural Insect Resources (NBAIR), Bangalore, India, without exposing to insecticides for 125 generations was used in the study as susceptible population.

\section{Laboratory rearing}

Chrysoperla zastrowi sillemi populations were maintained separately in the laboratory on UV exposed (15 watt for one h in UV hood) eggs of Corcyra cephalonica (Stainton). UV exposure of eggs was done in order to kill the embryo and facilitate the rearing of the Chrysoperla. Freshly emerged adults were transferred to oviposition chambers $(14 \mathrm{~cm} \times 9 \mathrm{~cm})$ covered with muslin cloth. Cotton swabs dipped in water and the other with $50 \%$ honey, proteinex (Pfizer limited, Mumbai, India) (consisting of pre-digested protein enriched with vitamins, carbohydrates and minerals), yeast and sucrose in the ratio of 1:1:1:1) and castor pollen grains was provided as adult feed and covered with perforated brown paper for egg laying. Eggs were collected at two-day intervals and kept for hatching with C. cephalonica eggs and the containers were covered with perforated brown paper. Freshly emerged larvae were kept individually in glass vials $(4 \times 2.5 \mathrm{~cm})$ plugged with cotton and fed on Corcyra eggs. The rearing was done at $26 \pm 1^{\circ} \mathrm{C}, 65 \pm 5 \% \mathrm{RH}$ at a photoperiod of $14 \mathrm{~L}: 10 \mathrm{D}$ in a plant growth chamber.

\section{Insecticides}

Commercial formulations of insecticides have been used for dosage mortality and synergism studies (Sayyed et al., 2010; Ahmad and Hollingwoth, 2004). Furthermore, field resistance has been always reported for commercial formulation of insecticides. Hence, the following formulated insecticides were used for bioassays and also for synergism studies: endosulfan 35 EC (Excel Crop Care Limited, Mumbai), fenvalerate 20 EC (Aimco pesticides Limited, Mumbai, India) and acephate $75 \%$ SP (Jai Radhe Sales, Ahmedabad, Gujarat, India). All other chemicals were of analytical grade and purchased from Sigma-Aldrich (Belgium).

\section{Dose mortality bioassays}

Based on the field recommended dosage of endosulfan $(0.07 \%)(2.0 \mathrm{ml} /$ litre $)$, fenvalerate $(0.04 \%)(0.2 \mathrm{ml} /$ litre $)$ and acephate $(0.05 \%)(0.67 \mathrm{~g} /$ litre $)$ in India, the following concentrations were used for the bioassay studies: endosul- 
fan $(0,0625,0.25,0.5,1.0,2.0,4.0,8.0,16.0,32.0,64.0$, $74.0,84.0,94.0 \mathrm{ml} / \mathrm{lit})$, fenvalerate $(0.2,0.4,0.8,1.6,3.2$, $6.4,12.8,25.6,51.2,61.2 \mathrm{ml} / \mathrm{lit})$ and acephate $(1.34,2.68$, 5.36, 10.72, 21.44, 42.88, 85.76, 171.52, 343.04, 686.08 $\mathrm{gm} / \mathrm{lit}$ ). These were applied on 3-d-old larvae of C. z. sillemi larvae in the weight range of 0.8 to $1.2 \mathrm{mg}$ by using topical assays (Pathan et al., 2008). Each insecticide was tested with seven concentrations initially and as we did not get $50 \%$ mortality, the number of concentrations were further increased to 13,10,10 for endosulfan, acephate and fenvalerate, respectively. Each concentration was replicated thrice to determine the $\mathrm{LC}_{50}$ value. The treated larvae were provided with Corcyra eggs and were reared in a growth chamber at a temperature and $\mathrm{RH}$ as mentioned earlier. Untreated (control) larvae were treated with distilled water alone. At least 30 larvae were used for each concentration and in control. The mortality was recorded after $48 \mathrm{~h}$ and the larvae were considered dead if they did not move when prodded.

\section{Synergism studies}

CZS-8 population of C. Z. sillemi, which had highest $\mathrm{LC}_{50}$ and resistant factor for all three groups of insecticides was selected for synergism studies. For synergism assays, the synergist piperonyl butoxide (PBO; $0.5 \mathrm{ul}(0.5 \mathrm{mg} / 100$ $\mathrm{ml})(90 \%$ purity), diethyl maleate (DEM: $0.5 \mathrm{ul}(0.5 \mathrm{mg} / 100$ ml) (97\% purity) and S,S,S-tributyl phosphorotrithioate (DEF; $0.5 \mathrm{ul}(0.5 \mathrm{mg} / 100 \mathrm{ml})(98 \%$ purity) were dissolved individually in a mixture of $\mathrm{N}, \mathrm{N}$,-dimethylformamide and tween- 80 ( $3: 1$ by weight) and subsequently diluted with de- ionised water (100-fold) [25]. Endosulfan @ 94.0 ml/liter, fenvalerate@61.2ml/liter and acephate@686.08 g/lit were mixed with water and a series of dilutions was made.

\section{Data analysis}

The results from all replicates for each insecticide were pooled and dose mortality regressions were computed by Probit analysis [Finney, 1952), using SPSS 16.0 software. Resistance ratio (RR) was calculated as $\mathrm{LC}_{50}$ of the field strain/LC $\mathrm{LC}_{50}$ of the susceptible strain. Synergism ratios and their confidence limits were calculated using the formula and statistics of dose ratios [Robertson and Preisler, 1992].

\section{RESULTS AND DISCUSSION}

\section{Toxicity Bioassays}

Among the 9 field and one laboratory populations of C. z. sillemi tested, Sriganganagar population (CZS-8) recorded maximum $\mathrm{LC}_{50}$ for endosulfan $(252.82 \mathrm{ml} / \mathrm{lit}$.) followed by the population from Delhi (CZS-5), Anand (CZS-4), Udaipur (CZS-9), Ludhiana (CZS-7) and Dharwad (CZS-2) and these were significantly different from all other populations (Table 2). The resistance ratio (RR) was highest (50.36-fold) in Sriganganagar (CZS-8) followed by Delhi (CZS-5) (26.02-fold), Anand (CZS-4) (21.46-fold) and Udaipur (CZS-9) population (15.4- fold). Non-overlapping test of significance indicated that between the populations, there was significant difference the populations, however, all the resistant populations, viz., CZS-1 to CZS9 were significantly different from susceptible population $(P \leq 0.01)$.

Table 1. Insecticide usage at sampling sites of Chrysoperla zastrowi sillemi on cotton 2007-2009 cropping seasons

\begin{tabular}{|c|c|c|c|c|c|c|}
\hline \begin{tabular}{|l|} 
S1. \\
No.
\end{tabular} & \begin{tabular}{|l|} 
Collection site \\
(District \&State-wise)
\end{tabular} & $\begin{array}{l}\text { Code } \\
\text { No. }\end{array}$ & $\begin{array}{l}\text { Collection } \\
\text { period }\end{array}$ & $\begin{array}{l}\text { Details of insecticides used and no. of sprays } \\
\text { (year prior to collection) }\end{array}$ & Latitude & Longitude \\
\hline 1 & $\begin{array}{l}\text { Coimbatore } \\
\text { (Tamil Nadu) }\end{array}$ & CZS-1 & April 2008 & $\begin{array}{l}\text { Triazophos, endosulfan, quinalphos, acephate } 75 \% \mathrm{SP} \text {, } \\
\text { fenitrothion } 3 \text { sprays/month) }\end{array}$ & $11^{\circ} 00^{\prime} \mathrm{N}$ & $77^{\circ} 00^{\prime} \mathrm{E}$ \\
\hline 2 & $\begin{array}{l}\text { Dharwad } \\
\text { (Karnataka) }\end{array}$ & CZS-2 & Sep-2009 & $\begin{array}{l}\text { Imidaclopid } 17.8 \mathrm{SL} \text {, thiomethaxam } 70 \mathrm{WS} \text {, oxydemeton } \\
\text { methyl } 25 \mathrm{EC} \text {, dimethoate } 30 \mathrm{EC} \& \text { endosulfan, } 35 \mathrm{EC} \\
\text { (3-5 sprays/month) }\end{array}$ & $15^{\circ} 27^{\prime} \mathrm{N}$ & $75^{\circ} 05^{\prime} \mathrm{E}$ \\
\hline 3 & $\begin{array}{l}\text { Guntur } \\
\text { (Andhra Pradesh) }\end{array}$ & CZS-3 & Dec.2008 & $\begin{array}{l}\text { Endosulfan,triazophos, profenphos, acephate } 75 \% \mathrm{SP} \text {, } \\
\text { indoxocarb (4-5 times/month) }\end{array}$ & $16^{\circ} 18^{\prime} \mathrm{N}$ & $80^{\circ} 29^{\prime} \mathrm{E}$ \\
\hline 4 & $\begin{array}{l}\text { Anand } \\
\text { (Gujarat) }\end{array}$ & CZS-4 & Nov. 2008 & $\begin{array}{l}\text { Fenvalerate } 20 \mathrm{EC} \text {, endosulfan } 35 \mathrm{EC} \text {, profenphos, spi- } \\
\text { nosad } 48 \mathrm{SC} \text {, acephate } 75 \% \mathrm{SP} \text { ( } 3 \text { sprays/month) }\end{array}$ & $22^{\circ} 32^{\prime} \mathrm{N}$ & $73^{\circ} 00^{\prime} \mathrm{E}$ \\
\hline 5 & Delhi & CZS-5 & Oct. 2008 & $\begin{array}{l}\text { Acephate } 75 \% \text { WP, oxydemeton methyl } 25 \mathrm{EC} \text {, } \\
\text { dimethoate } 30 \mathrm{EC} \text { ( } 3 \text { sprays/month) }\end{array}$ & $28^{\circ} 38^{\prime} \mathrm{N}$ & $77^{\circ} 12^{\prime} \mathrm{E}$ \\
\hline 6 & $\begin{array}{l}\text { Sirsa } \\
\text { (Haryana) }\end{array}$ & CZS-6 & Oct. 2008 & $\begin{array}{l}\text { Acephate, triazophos, spinosad, indoxocarb, fenvalerate } \\
\text { (4 sprays/month) }\end{array}$ & $29^{\circ} 53^{\prime} \mathrm{N}$ & $75^{\circ} 020^{\prime} \mathrm{E}$ \\
\hline 7 & $\begin{array}{l}\text { Ludhiana } \\
\text { (Punjab) }\end{array}$ & CZS-7 & May 2009 & $\begin{array}{l}\text { Acephate, triazophos, spinosad, indoxocarb, fenvalerate } \\
\text { (4 sprays/month) }\end{array}$ & $30^{\circ} 55^{\prime} \mathrm{N}$ & $75^{\circ} 54^{\prime} \mathrm{E}$ \\
\hline 8 & $\begin{array}{l}\text { SriGanganagar } \\
\text { (Rajasthan) }\end{array}$ & CZS-8 & Oct. 2008 & $\begin{array}{l}\text { oxydemeton methyl } 25 \mathrm{EC} \text {, dimethoate } 30 \mathrm{EC} \text {, acephate } \\
75 \% \mathrm{SP} \text {, phosphamidon } 85 \mathrm{WSC} / \mathrm{ha} \text { (3-4 sprays/month) }\end{array}$ & $29^{\circ} 49^{\prime} \mathrm{N}$ & $73^{\circ} 50^{\prime} \mathrm{E}$ \\
\hline 9 & \begin{tabular}{|l} 
Udaipur \\
(Rajasthan)
\end{tabular} & CZS-9 & Feb. 2009 & $\begin{array}{l}\text { Acephate } 75 \% \mathrm{WP} \text {, oxydemeton methyl } 25 \mathrm{EC} \text {, } \\
\text { dimethoate } 30 \mathrm{EC} \text {, phosphamidon } 85 \mathrm{WSC} / \mathrm{ha}(3-4 \\
\text { sprays/month) }\end{array}$ & $27^{\circ} 42^{\prime} \mathrm{N}$ & $75^{\circ} 33^{\prime} \mathrm{E}$ \\
\hline
\end{tabular}


Table 2. Toxicity of endosulfan to field collected and lab reared (susceptible) Chrysoperla zastrowi sillemi

\begin{tabular}{|l|l|l|l|l|l|l|l|}
\hline Strain & $\mathrm{n}$ & Slope $\pm \mathrm{SE}$ & $\begin{array}{l}\mathrm{LC}_{50} \\
\mathrm{~g} / \text { lit or } \mathrm{ml} / \mathrm{lit})\end{array}$ & $95 \% \mathrm{FL}$ & $x^{2}$ & $\begin{array}{l}\text { Probability } \\
p\end{array}$ & RR \\
\hline CZS-1 & 210 & $0.615 \pm 0.449$ & $21.21^{\mathrm{b}}$ & $14.18-32.23$ & 5.4 & 0.75 & 4.2 \\
\hline CZS-2 & 215 & $1.35 \pm 0.805$ & $69.12^{\mathrm{a}}$ & $39.22-436.45$ & 1.518 & 0.997 & 13.76 \\
\hline CZS-3 & 230 & $1.95 \pm 1.09$ & $54.36^{\mathrm{a}}$ & $31.46-78.93$ & 1.71 & 0.998 & 10.82 \\
\hline CZS-4 & 211 & $3.34 \pm 1.76$ & $107.75^{\mathrm{a}}$ & $84.51-1222.67$ & 1.29 & 1.000 & 21.46 \\
\hline CZS-5 & 212 & $3.85 \pm 2.04$ & $130.60^{\mathrm{a}}$ & $87.46-1262.86$ & 6.76 & 0.818 & 26.02 \\
\hline CZS-6 & 240 & $1.72 \pm 1.09$ & $36.89^{\mathrm{b}}$ & $22.0-64.96$ & 0.625 & 0.996 & 7.34 \\
\hline CZS-7 & 218 & $2.451 \pm 1.35$ & $70.41^{\mathrm{a}}$ & $54.31-106.51$ & 6.91 & 0.621 & 14.02 \\
\hline CZS-8 & 225 & $0.982 \pm 0.586$ & $252.82^{\mathrm{a}}$ & $87.46-3235.14$ & 1.55 & 0.997 & 50.36 \\
\hline CZS-9 & 220 & $1.28 \pm 0.79$ & $77.31^{\mathrm{a}}$ & $50.45-166.90$ & 6.68 & 0.824 & 15.4 \\
\hline CZS-10@ & 240 & $0.792 \pm 0.617$ & $5.02^{\mathrm{c}}$ & $3.49-7.07$ & 1.033 & 0.984 & \\
\hline
\end{tabular}

$\mathrm{n}=$ Number of larvae used in bioassay, including controls.

$\mathrm{RR}=$ Resistance Ratio, calculated as $\mathrm{LC}_{50}$ of field collected (or resistance) strain $/ \mathrm{LC}_{50}$ of susceptible

$@=$ lab reared susceptible population

Means within a column followed by different letters are significantly different $(P<0.01$; non-overlapping of $95 \%$ FL $)$

Abbreviations: $\mathrm{LC}=$ Lethal Concentration expressed as gm/larva; FL= Fiducial limits; $\mathrm{SE}=\mathrm{Standard}$ Error; $\mathrm{RR}=\mathrm{Re}$ istance Ratio

$*=P \geq 0.05$ indicates s significant fit between the observed and expressed regression lines in a probit analysis.

In the test of significance by non-overlapping method, for fenvalerate, CZS-8 recorded high resistance $(81.98 \mathrm{ml} /$ litre) which was on par with Delhi, Ludhiana, Anand and Dharwad populations and were significantly different from remaining field populations. $\mathrm{LC}_{50}$ of all the field populations were significantly different from susceptible population $(P \leq 0.01)$. Resistance ratio (RR) for fenvalerate ranged from 9.12 to 66.11 -fold in the 9 populations. The highest RR was recorded in CZS-8 (66.11-fold) followed by CZS-5 (38.89-fold), CZS-9 (25.91-fold), CZS-4 (21.64-fold) and
CZS-6 (17.94-fold) (Table 3).

Resistance to acephate was highest in Sriganganagar population (CZS-8) (535.60 g/litre) which was significantly at par with CZS-9, CZS-6, CZS-3 and CZS-1 and were significantly superior to rest of the populations (Table 4). The study showed that C. $z$. sillemi had cross resistance to different groups of insecticides, viz., endosulfan, fenvalerate and acephate.

Table 3. Toxicity of fenvalerate to field collected and lab reared (susceptible) Chrysoperla zastrowi sillemi

\begin{tabular}{|l|l|l|l|l|l|l|l|}
\hline Strain & $\mathrm{n}$ & Slope $\pm \mathrm{SE}$ & $\begin{array}{l}\mathrm{LC}_{50} \\
\mathrm{~g} / \mathrm{lit} \text { or } \mathrm{ml} / \mathrm{lit}\end{array}$ & $95 \% \mathrm{FL}$ & $x^{2}$ & $\begin{array}{l}\text { Probability } \\
P^{*}\end{array}$ & RR \\
\hline CZS-1 & 240 & $0.272+.214$ & $11.32^{\mathrm{b}}$ & $7.02-19.21$ & 3.36 & 0.971 & 9.12 \\
\hline CZS-2 & 225 & $0.640 \pm 0.529$ & $17.52^{\mathrm{a}}$ & $8.08-57.84$ & 1.39 & 0.966 & 14.12 \\
\hline CZS-3 & 211 & $1.19 \pm 0.933$ & $14.93^{\mathrm{b}}$ & $8.92-22.48$ & 1.23 & 1.000 & 12.04 \\
\hline CZS-4 & 223 & $0.66 \pm 0.517$ & $26.84^{\text {a }}$ & $16.93-58.12$ & 1.59 & 0.991 & 21.64 \\
\hline CZS-5 & 210 & $2.35 \pm 1.48$ & $48.23^{\text {a }}$ & $36.46-99.20$ & 0.127 & 0.988 & 38.89 \\
\hline CZS-6 & 215 & $0.455 \pm 0.359$ & $22.25^{\mathrm{b}}$ & $13.57-44.77$ & 5.37 & 0.865 & 17.94 \\
\hline CZS-7 & 210 & $0.620 \pm 0.448$ & $24.26^{\text {a }}$ & $12.73-54.70$ & 3.26 & 0.860 & 19.56 \\
\hline CZS-8 & 215 & $1.112 \pm 0.704$ & $81.98^{\text {a }}$ & $48.72-758.39$ & 0.847 & 0.932 & 66.11 \\
\hline CZS-9 & 230 & $2.004 \pm 1.26$ & $32.14^{\mathrm{b}}$ & $18.4-46.07$ & 1.48 & 0.993 & 25.91 \\
\hline CZS-10@ & 212 & $0333 \pm 0.2$ & $1.24^{\mathrm{c}}$ & $0.48-2.762$ & 2.23 & 0.973 & \\
\hline
\end{tabular}

$\mathrm{n}=$ Number of larvae used in bioassay, including controls.

$\mathrm{RR}=$ Resistance Ratio, calculated as $\mathrm{LC}_{50}$ of field collected (or resistance) strain $/ \mathrm{LC}_{50}$ of susceptible

$@=$ lab reared susceptible population

Means within a column followed by different letters are significantly different $(P<0.01$; non-overlapping of $95 \% \mathrm{FL})$

Abbreviations: $\mathrm{LC}=$ Lethal Concentration expressed as gm/larva; $\mathrm{FL}=$ Fiducial limits; $\mathrm{SE}=$ Standard Error; $\mathrm{RR}=$ Resistance Ratio

$*=P \geq 0.05$ indicates s significant fit between the observed and expressed regression lines in a probit analysis. 
Table 4. Toxicity of acephate to field collected and lab reared (susceptible) Chrysoperla zastrowi sillemi

\begin{tabular}{|l|l|l|l|l|l|l|l|}
\hline Strain & $\mathrm{n}$ & Slope $\pm \mathrm{SE}$ & $\begin{array}{l}\mathrm{LC}_{50} \\
\mathrm{~g} / \text { lit } \text { or } \mathrm{ml} / \mathrm{lit}\end{array}$ & $95 \% \mathrm{FL}$ & $\chi^{2}$ & $\begin{array}{l}\text { Probability } \\
p\end{array}$ & RR \\
\hline CZS-1 & 223 & $2.61 \pm 1.09$ & $384.02^{\mathrm{a}}$ & $260.95-1565.43$ & 0.958 & 1.000 & 198.97 \\
\hline CZS-2 & 210 & $0.792 \pm 0.617$ & $5.02^{\mathrm{c}}$ & $3.49-7.07$ & 1.033 & 0.984 & 2.60 \\
\hline CZS-3 & 230 & $2.47 \pm 0.952$ & $501.63^{\mathrm{a}}$ & $326.93-1114.73$ & 8.09 & 0.778 & 259.91 \\
\hline CZS-4 & 215 & $7.71 \pm 5.6$ & $5.30^{\mathrm{c}}$ & $3.52-7.92$ & 0.026 & 1.00 & 2.74 \\
\hline CZS-5 & 230 & $1.201 \pm 1.01$ & $12.66^{\mathrm{b}}$ & $9.26-16.05$ & 1.86 & 0.967 & 6.55 \\
\hline CZS-6 & 210 & $2.43 \pm 1.06$ & $255.04^{\text {a }}$ & $171.12-564.53$ & 2.5 & 0.996 & 132.14 \\
\hline CZS-7 & 215 & $0.455 \pm 0.359$ & $22.25^{\mathrm{b}}$ & $13.57-44.77$ & 5.37 & 0.865 & 11.52 \\
\hline CZS-8 & 210 & $2.61 \pm 0.98$ & $535.60^{\mathrm{a}}$ & $362.98-1041.18$ & 1.84 & 0.985 & 277.51 \\
\hline CZS-9 & 218 & $1.93 \pm 0.782$ & $317.88^{\mathrm{a}}$ & $192.49-585.41$ & .2 .8 & 0.946 & 164.70 \\
\hline CZS-10@ & 212 & $1.04 \pm 0.59$ & $1.93^{\mathrm{c}}$ & $0.163-3.604$ & 0.457 & 1.00 & \\
\hline
\end{tabular}

$\mathrm{n}=$ Number of larvae used in bioassay, including controls.

$\mathrm{RR}=$ Resistance Ratio, calculated as $\mathrm{LC}_{50}$ of field collected (or resistance) strain $/ \mathrm{LC}_{50}$ of susceptible @ $=$ lab reared susceptible population

Means within a column followed by different letters are significantly different $(P<0.01$; non-overlapping of $95 \% \mathrm{FL})$

Abbreviations: $\mathrm{LC}=$ Lethal Concentration expressed as gm/larva; FL = Fiducial limits; $\mathrm{SE}=\mathrm{Standard}$ Error; RR= Resistance Ratio

$*=P \geq 0.05$ indicates s significant fit between the observed and expressed regression lines in a probit analysis.

In India, insecticides are the most common means of controlling the pests by farmers and acephate, fenvalerate and endosulfan are the most widely used insecticides against sucking pests on cotton (Radika and Subbaratnam, 2006; Dhawan et al., 2009). Armes et al. (1994) reported that use of increasing number of insecticide brands, spurious insecticide use, lack of proper recommendations are the some of the reasons for the pest management problems in India. As a result insect pests developed resistance to different groups of insecticides which forces the farmers to go for increased number of insecticides to combat the pests. Kranthi et al. (2001) reported that many insect pests have developed resistance to these insecticides on cotton. Since the introduction of Bt cotton in India, frequency of insecticides applied against bollworms has come down drastically, however, sucking pests like aphids, whiteflies, thrips, mealybugs and leafhoppers are a serious bottleneck for successful cultivation of cotton and insecticides are increasingly applied to combat such pests. However, studies on development of insecticide resistance in natural enemies are very scanty. In this connection, insecticide resistant $C$. z. sillemi would be useful for the effective suppression of sucking pests as they can survive and multiply in sprayed situation.

Field strains of $H$. armigera exhibited widespread resistance to synthetic pyrethroid (cypermethrin) with 23-8022-fold resistances. Resistance to endosulfan (23-57fold) and chlorpyriphos (4-82-fold) was low to high in $\mathrm{H}$. armigera was observed. Besides, Spodoptera litura, Earias vitella and Bemisia tabaci from cotton filed developed moderate to high level of resistance to pyrethroid, organophosphate and cyclodiene in India (Dhawan et al., 2009). Some of the field collected populations of C. z. sillemi showed high resistance to acephate, fenvalerate and endosulfan in this study. This shows clearly that C. z. sillemi, which is the dominant predator found in cotton has developed resistance to different groups of insecticides along with insect pests in India. The enhanced resistance in Sriganganagar population (CZS-8) of C. z. sillemi correlates well with the greater use of insecticides in that region, particularly on cotton, where on average of 8-22 rounds of sprays of insecticides were used against a complex of insect pests [Kranthi et al., 2001]. The development of insecticide resistance in C. $z$. sillemi is primarily a result of the selection pressure exerted on sprayed populations increasing the frequency of resistant individuals which perhaps would have altered the genetic make-up of the organisms to survive and withstand higher doses of insecticides. Venkatesan et al. [2009] reported that out of the 9 field populations of C. z. sillemi, Sriganganagar (Rajasthan, India) population exhibited very high resistance to monocrotophos as compared to laboratory population. The study further supports our findings that the predator from Sriganganagar (CZS-8) developed resistance not only to monocrotophos but also to endosulfan, fenvalerate and acephate with RR increased to 50.36-fold, 66.11-fold and 277.51-fold, respectively, compared to susceptible. Sayyed et al. (2010) reported RRs of 47, 86, 137, 76 and 110 for deltamethrin, alphamethrin, lamdacyhalothrin, chlorpyrifos and profenofos for resistant $C$. carnea as compared to lab population in Pakistan, which was in conformity with our study. Natural tolerance to pyrethroid in $C$. carnea has been reported [Plapp and Bull, 1978). Further, Croft and Brown [1975] reported that natural enemies were more tolerant than their prey or host (67 of 92 cases) and predators were more tolerant than their prey (63 of 77 cases). Among the 
natural enemies, Amblyseius chilenensis was the first predatory mite found resistant to chemical pesticides (Kranthi et al., 2002). Similarly, insecticide resistance in different geographical populations of Chrysoperla carnea in Pakistan was earlier reported [Pathan et al., 2008; Sayyed et al., 2010; Venkatesan et al., 2009). Hence it may correct that chrysopid predators in India and Pakistan is being increasingly developed resistance to insecticides especially from the cotton which could be due to heavy insecticidal sprays used to control the sucking pests especially for the newly introduced cotton mealybug Phenococus solenopsis.

\section{Synergism studies}

The population CZS-8 was selected for synergism studies based on their higher $\mathrm{LC}_{50}$ and RR. PBO had different effects on the toxicity of endosulfan, fenvalerate and acephate (Table 5) to insecticide resistant (CZS-8) and susceptible populations. PBO caused an 8.97-fold increase in toxicity of endosulfan, 0.855 -fold for fenvalerate and 54.32fold for acephate. DEF caused an 18.49-fold increase in toxicity of endosulfan in CZS-8 population. The synergism of DEF on fenvalerate in CZS- 8 population enhanced the toxicity by 8.69 -fold and DEF showed obvious synergism. On acephate in the same strain, the synergism increased to 8.69-fold. The synergism of DEM on endosulfan enhanced the toxicity by 6.38 -fold; 3.63 -fold for endosulfan, fenvalerate, respectively and 113.52-fold for acephate. Synergism was found to be very low when the effect of PBO was tested on resistance for fenvalerate in CZS-8. However, a synergistic effect could be detected in those populations when treated with DEF with endosulfan, fenvalerate and acephate. DEF produced a very high synergistic effect on acephate (SR ratio: 150.87) followed by endosulfan (SR ratio: 18.49 ) and fenvalerate (SR ratio: 8.69 ). This shows that DEF enhanced synergism in acephate, fenvalerate and endosulfan.

Table 5. Toxicity of endosulfan, fenvalerate and acephate with and without synergists to insecticide resistant and susceptible strains of Chrysoperla zastrowi sillemi

\begin{tabular}{|c|c|c|c|c|c|}
\hline Population & Treatment & Slope \pm SE & $\mathrm{LC}_{50}$ & $(95 \%$ CL) & SR \\
\hline \multirow[t]{4}{*}{$\mathrm{Lab}$} & Endosulfan & $0.792 \pm 0.617$ & 5.02 & 22-64.96 & ---- \\
\hline & $+\mathrm{PBO}$ & $0.239 \pm 0.220$ & 3.202 & $1.23-6.64$ & 1.57 \\
\hline & $+\mathrm{DEF}$ & $0.268 \pm 0.232$ & 4.85 & $1.22-11.16$ & 1.03 \\
\hline & + DEM & $0.268 \pm 0.243$ & 2.35 & $0.32-5.56$ & 2.1 \\
\hline \multirow[t]{4}{*}{ CZS-8 } & Endosulfan & $0.982 \pm 0.586$ & 252.82 & $87.46-3.23$ & --- \\
\hline & $+\mathrm{PBO}$ & $1.26 \pm 0.875$ & 28.180 & 19.89-42.02 & $8.97^{\mathrm{a}}$ \\
\hline & $+\mathrm{DEF}$ & $1.146 \pm 0.997$ & 13.67 & 9.99-19.13 & $18.49^{\mathrm{a}}$ \\
\hline & + DEM & $0.502 \pm 0.298$ & 39.62 & 25.06-63.33 & $6.38^{\mathrm{a}}$ \\
\hline \multirow[t]{4}{*}{ Lab } & Fenvalerate & $0.333 \pm 0.2$ & 1.24 & $0.48-2.762$ & --- \\
\hline & $+\mathrm{PBO}$ & $0.204 \pm 0.182$ & 1.041 & $0.26-5.296$ & 1.19 \\
\hline & + DEF & $1.088 \pm 0.281$ & 1.152 & $0.106-2.88$ & 1.07 \\
\hline & + DEM & $0.254 \pm 0.233$ & 1.23 & $0.01-4.86$ & 1.00 \\
\hline \multirow[t]{4}{*}{ CZS-8 } & Fenvalerate & $1.112 \pm 0.704$ & 81.98 & $48.72-758.39$ & ---- \\
\hline & $+\mathrm{PBO}$ & $4.504 \pm 2.61$ & 95.85 & --- & 0.855 \\
\hline & $+\mathrm{DEF}$ & $0.342 \pm 0.302$ & 9.43 & $5.52-17.6$ & $8.69^{a}$ \\
\hline & + DEM & $0.782 \pm 0.559$ & 22.55 & 15.28-33.39 & $3.63^{\mathrm{a}}$ \\
\hline \multirow[t]{4}{*}{ Lab } & Acephate & $1.04 \pm 0.59$ & 1.93 & $0.163-3.604$ & --- \\
\hline & $+\mathrm{PBO}$ & $0.198 \pm 0.181$ & 1.101 & 0.006-4.818 & 1.75 \\
\hline & $+\mathrm{DEF}$ & $0.239 \pm 0.191$ & 1.554 & 0.64-2.9 & 1.24 \\
\hline & + DEM & $0.214 \pm 0.153$ & 1.492 & $0.026-27.05$ & 1.29 \\
\hline \multirow[t]{4}{*}{ CZS-8 } & Acephate & $2.61 \pm 0.98$ & 535.60 & 362.98-1041.18 & --- \\
\hline & $+\mathrm{PBO}$ & $0.839 \pm 0.806$ & 9.86 & 6.92-13.94 & $54.32^{\mathrm{a}}$ \\
\hline & $+\mathrm{DEF}$ & $0.954 \pm 0.588$ & 3.55 & 2.54-4.93 & $150.87^{\mathrm{a}}$ \\
\hline & + DEM & $0.502+0.298$ & 39.62 & 25.06-63.33 & $113.52^{a}$ \\
\hline
\end{tabular}

Synergism Ratio (SR)- $\mathrm{LC}_{50}$ of insecticide alone $/ \mathrm{LC}_{50}$ of insecticide + synergist.

Abbreviations: $\mathrm{LC}=$ Lethal Concentration expressed as gm/larva; FL= Fiducial limits; $\mathrm{SE}=$ Standard Error

a There is significant synergism based on on-overlapping of the $95 \%$ CL's of the $\mathrm{LC}_{50}$ values between insecticide only and insecticide after synergists treatment. 
Pyrethroid resistance has been attributed to reduced neural sensitivity, enhanced metabolism and reduced penetration ratio in many insects [Oppenoorth, 1985; Zerba et al., 1987). Atkinson et al. (1991) reported that permethrin and cypermethrin resistance in a highly pyrethroid resistant strain of Blattella germanica was partially suppressed with PBO and DEF, thus suggesting the involvement of enhanced metabolism as well as target site insensitivity in the mechanism of resistance. Picollo et al. [2000] reported that enhanced metabolism and synergism by enzyme inhibitor was involved in pyrethroid resistance in Pediculus capitis. The activation by midgut esterases from the tobacco hornworm, Manduca sexta (L.) was inhibited by DEF (Kranthi et al., 2002). Sayyed et al. (2010) demonstrated that PBO reduced the $\mathrm{LC}_{50}$ for deltamethrin ( 8 fold), alphamethrin (3-fold) and lambdacyhalothrin (1.6-fold) in deltamethrin resistant strain of $C$. carnea which is in conformity with our present study.

In the current study, in case of resistance to acephate, PBO did decrease the resistance in CZS-8 population. This shows that the PBO block esterase activity which perhaps plays an important role in detoxification of acephate. Similarly, PBO had also been reported to inhibit resistance related esterases in some insect species (Wing et al., 1998; Gunning et al., 1998; Gunning et al., 1999). DEF played a role in detoxification of endosulfan, fenvalerate and acephate in all the populations by increasing synergism ratio in the present investigation. This suggests that DEF could inhibit monoxygenase, esterase and GST activities which are in accordance with earlier studies that it is not a completely specific inhibitor of esterase that it can also inhibit monoxygenase at high concentration (Young et al., 2005; Valles et al., 1997). Similarly, DEM also suppressed the toxicity of endosulfan, fenvalerate and acephate by increasing the synergism which indicates the activity of monoxygenase, esterase and GST. The combined evidence of in vitro and synergism bioassays indicate that the insecticide resistance in C. z. sillemi could be due to either enhanced esterase and or monooxygenase and GST activities.

Though synergism bioassays and in vitro enzyme assays indicated that metabolic detoxification was an important resistance mechanism, the fact that full suppression of resistance was never achieved in any of the populations suggests that metabolic detoxification was probably one of the many mechanisms conferring insecticide resistance. Sayyed et al. (2010) reported that resistant natural enemies could be an alternative option to use them in concurrence with insecticides. They found that $C$. carnea developed cross resistance to pyrethroid and organophosphate compounds which is in accordance with our study.
Detoxification enzymes are similar in most of the insects including pests and natural enemies and the high esterase activity in lacewing larvae contributed to natural tolerance to pyrethroids (Dhawan et al., 2009). Bozsik et al. (2002) reported that $C$. carnea was tolerant to paraoxon (organophosphate group) due to higher activity of acetyl cholinesterase (AChE). Mixed-function oxidases (MFO) and hydrolysing esterases may be involved in detoxification of carbaryl resistant strain of $C$. carnea larvae. Further, Grafton \& Hoy (1985) found that C. carnea possesses naturally high esterase enzyme levels that provide them natural resistance for pyrethroids. Further, monoxygenasemediated resistance to pyrethroids was found in C. carnea (Pree et al., 1989) which are in conformity with our study. Insecticide resistant selected C. carnea may tolerate insecticide pressure in the field conditions (Sayyed et al., 2010). The study revealed the selection of insecticide resistant $C$. z. sillemi which can be used in the IPM programs. Sayyed et al. (2010) opined that release of insecticide resistant $C$. carnea will survive for the field dosage of pesticides and also inherit all genes involved in insecticide resistance to subsequent generations.

The study clearly showed that the field populations of Chrysoperla zastrowi sillemi from cotton developed resistance for insecticides belonging to pyrethroids, organophosphate and cyclodiene. Among the resistant populations, CZS-8 had been found to have greater RRs to different insecticides, hence may be considered for the field evaluation. This is the first kind of such study in India. Mass production and release of such resistant predator would improve their survival in sprayed situations for potential use in augmentative biological control or integrated pest management strategies in not only on cotton but also on other crops. Further, such predators can play an effective role in suppressing the insecticide resistant pest populations and resurgence of secondary pests.

\section{ACKNOWLEDGEMENTS}

The authors are also grateful to the Director, ICARNBAIR, Bangalore, India for providing necessary facilities for conducting the study.

\section{REFERENCES}

Ahmad M, Hollingwoth R. 2004. Synergism of insecticides provides evidence of metabolic mechanisms of resistance in the obliquebanded leafroller Choritoneura rosaceana (Lepidoptera: Tortricidae). Pest MAnag Sci. 60: 465-473. Crossref PMid:15154513

Armes NJ, Banerjee SK, DeSouza KR, Jadhav DR, King ABS, Kranthi KR, Regupathy A, Surulivelu T, Rao 
NV. 1994. Insecticide resistance in Helicoverpa armigera in India: recent developments. pp. 437-442. In Brighton Crop Protection Conference-Pests and Diseases-1994. The British Crop Protection Council. Farham, UK.

Atkinson TH, Wadleigh RW, Koehler PG, Patterson RS. 1991. Pyrethroid resistance and synergism in a field strain of the German cockroach (Dictyoptera: Blattellidae). J Econ Entomol. 84: 1247-1250. Crossref PMid:1842795

Bozsik A, Francis F, Gaspar C, Haubruge E. 2002. Effect of some insecticides on acetyl cholinesterase from beneficial insects: Coccinella septempunctata, Chrysoperla carnea and Forficula auricularia Mededelingen Faculteit Landbouwkundige en Toegepaste Biologische Wetenchappen, Universiteit Gent. 67: 671-677.

Casida J. 1970. Mixed function oxidase involvement in the biochemistry of insecticide synergists J. Agric. Food Chem. 18: 753-772.

Croft BA, Brown AWA. 1975. Responses of arthropod natural enemies to insecticides. Annu Rev Entomol. 10: 285-335. Crossref PMid:234711

Croft BA, Briozzo J, Carbonell JW. 1976. Resistance to organophosphorous insecticides in a predaceous mite, Amblyseius chilenensis (Acarna: Phytoseidae). Econ Entomol. 69: 563- Crossref

Dhawan AK, Singh S, Kumar S. 2009. Integrated Pest Management (IPM) helps to reduce pesticide load in cotton. J Agric Sci Tech. 11: 275-282

Finney DJ. 1952. Probit Analysis. 2nd edition. Cambridge University. Press. 250 pp.

Grafton-Cardwell EE, Hoy A. 1985. Intraspecific variability in response to pesticides in the common green lacewing, Chrysoperla carnea (Stephens) (Neuroptera: Chrysopidae). Hilgardia 53: 1-31. Crossref

Gunning RV, Moores GD, Devonshire AL. 1998. Inhibition of resistance-related esterases by piperonyl butoxide in Helicoverpa armigera (Lepidoptera:Noctuidae) and Aphis gossypii (Hemiptera: Aphididae). pp. 215227 in: Jones, D.G. (Ed.) Piperonyl butoxide: The Insecticide Synergist, London, Academic Press.

Gunning RV, Moores GD, Devonshire AL. 1999. Esterase inhibitors synergise the toxicity of pyrethroids in Australian Helicoverpa armigera (Hubner)
(Lepidoptera: Noctuidae). Pestic Biochem Physiol. 63: 50-62. Crossref

Henry CS, Brooks SJ, Johnson JB, Venkatesan T, Duelli P. 2010. The most important lacewing species in Indian agricultural crops, Chrysoperla sillemi (EsbenPetersen), is a subspecies of Chrysoperla zastrowi (Esben-Petersen) (Neuroptera: Chrysopidae). J Nat His. 44: 2543-2555. Crossref

Kranthi KR, Jadhav DR, Wanjari R, Ali S, Russel DA. 2001. Carbamate and organophosphate resistance in cotton pests in India, 1995 to 1999. Bull Entomol Res. 91: 37-46. PMid:11228586

Kranthi, KR, Jadhav DR, Kranthi S, Wanjari RR, Ali SS, Russell DA. 2002. Insecticide resistance in five major insect pests of cotton in India. Crop Prot. 21: 6: 449460. Crossref

LI XC, Schuler MA, Berenbaum MR. 2007. Molecular mechanisms of metabolic resistance to synthetic and natural xenobiotics. Annu Rev Entomol. 52: 231-253. Crossref PMid: 16925478

Medina P, Budia PF, Del Estal P, Vi-uela V. 2003. Effect of three modern insecticides, pyriproxyfen, spinosad and tebufenozide, on survival and reproduction of Chrysoperla carnea adults. Ann Appl Biol. 142: 55. Crossref

Motoyama N. 1980. Glutathione-S-transferases, their role in the metabolism of organophosphorous insecticides. Rev Biochem Toxicol. 2: 49-69.

Narahashi T, Carter DB, Frey J, Ginsburg K, Hamilton BJ, Nagata K, Roy ML, Song J, Tatebayashi H. 1995. Sodium Channels and GABAA receptor-channel complex as targets of environmental toxicants. Toxicol Lett. 82/83: 239-245. Crossref

Oppenoorth FJ. 1985. Biochemistry and genetics of insecticide resistance. pp. 731-773, In: Kerkut GA, Gilbert CI (Eds.). Comprehensive insect physiology, biochemistry and pharmacology, vol. 12. Pergamon, Oxford, UK.

Pathan AK, Sayyed AH, Aslam M, Razaq, M, Jilani G, Saleem MA. 2008. Evidence of field-evolved resistance to organophosphates and pyrethroids in Chrysoperla carnea (Neuroptera: Chrysopidae). J Econ Entomol. 101: 1676-84. Crossref PMid:18950051

Pathan AK, Sayyed, AH, Aslam M, Liu, TX, Razaq M, Gillani, WA. 2010. Resistance to pyrethroids and 
organophosphates increased fitness and predation potential of Chrysoperla carnea (Neuroptera: Chrysopidae). J Econ Entomol. 103: 823-834. Crossref PMid:20568629

Picollo MI, Vassena CV, Mougabure C, Bernetti M, Zerba EN. 2000. Resistance to insecticides and effect of synergists on permethrin toxicity in Pediculus capitis (Anoplura: Pediculidae) from Buenos Aires. $J$ Med Entomol. 37: 721-725. Crossref PMid:11004784

Plapp FWJ, Bull DL. 1978. Toxicity and selectivity of some insecticides to Chrysoperla carnea, a predator of the tobacco budworm. Environ Entomol. 7: 431-434. Crossref

Pree DJ, Archibald DE, Morrison RK. 1989. Resistance to insecticides in the common green lacewing Chrysoperla carnea (Neuroptera: Chrysopidae) in southern Ontorio. J Econ Entomol. 82: 29-54. Crossref

Radika P, Subbaratnam GV. 2006. Insecticide resistance management in cotton- Indian Scenario. A review. Agric Rev. 27: 157-169.

Reddy AS, Rao NV. 1989. Cotton whitefly review. Indian J Plant Prot. 17: 171-179.

Robertson JL, Preisler HK. 1992. Pesticide Bioassays with Arthropods. 1st Edn., CRC Press, Boca Raton, Florida, ISBN-10: 0849364639, pp. 35-48.

Scott JG. 1990. Investigating mechanisms of insecticide resistance methods, strategies and pitfalls. pp. 39-57 In: Roush RT, Tabashnik BE (Eds.). Pesticide resistance in Arthropods, New York, Chapman \& Hall. Crossref PMid:10107655

Sayyed AH, Pathan AK, Faheem U. 2010. Cross-resistance, genetics and stability of resistance to deltamethrin in a population of Chrysoperla carnea from Multan, Pakistan. Pestic Biochem Physiol. 98: 325-332. Crossref

Symondron WUC, Sunderland KD, Greenstone MH. 2002. Can generalist predator be effective biocontrol agents? Ann Rev Entomol. 47: 561-594. Crossref PMid:11729085

Valles SM, Koehler, PG, Brenner RJ. 1997. Antagonism of fipronil toxicity by piperonyl butoxide and S,S,Stributyl phophoro trithioate in the German cockroach (Dictyoptera: Blatellidae). J Econ Entomol. 90: 12541258. Crossref
Van Pottelberge S, Van Leeuwen T, Nauen R, Tirry L. 2009. Resistance mechanisms to mitochondrial electron transport inhibitors in a field collected strain of Tetranychus urticae Loch (Acari: Tetranychidae). Bull Ent Res. 99: 23-31. Crossref PMid:18590597

Venkatesan T, Poorani, J, Jalali, S.K, Srinivasamurthy, K, Ashok Kumar, K, Lalitha Y, Rajeshwari R. 2008. Confirmation of the occurrence of Chrysoperla zastrowi arabica Henry et al. (Neuroptera: Chrysopidae) in India. J Biol Control 22: 143-147.

Venkatesan T, Jalali, SK, Murthy KS, Rabindra RJ, Lalitha Y. 2009. Occurrence of insecticide resistance in field populations of Chrysoperla zastrowi arabica Henry et al. (Neuroptera: Chrysopidae) in India. Indian J Agric Sci. 79: 910-912.

Wing KD, Schnee ME, Sacher M, Connair M. 1998. A novel oxadiazine insecticide is bioactivated in lepidopteran larvae. Arch Insect Biochem Physiol. 37: 91-103. Crossref

Wu G, Jiang SB, Miyata T. 2004. Seasonal changes of methamidophos susceptible and biochemical properties in Plutella xylostella (Lepidoptera: Yponomeutidae) and its parasitoid Cotesisa plutellae (Hymenoptera: Braconidae). J Econ Entomol. 97: 1689-1698. Crossref PMid:15568361

Wu G, Miyata T. 2005. Susceptibilities to methamidophos and enzymatic characteristics in 18 species of pest insects and their natural enemies to crucifer vegetable crops. Pestic Biochem Physiol. 82: 79-93. Crossref

Yang RSH. 1976. Enzyme conjucation and insecticide metabolism. pp. 177-181. In: Wilkinson CF (Ed.). Biochemistry and Physiology of Insecticides. Plenum, New York. Crossref

Young SJ, Gunning RV, Moores GD. 2005. The effect of piperonyl butoxide on pyrthroid-resistance-associated esterases in Helicoverpa armigera (Hubner) (Lepidoptera: Noctuidae). Pest Manag Sci. 61: 397401. Crossref PMid:15605351

Zerba EN, De Licastro S, Wood E, Picollo MI. 1987. Insecticide mechanism of action, pp.103-106. In: Brenner R, Stoka A (Eds.) Chagas disease vectors. Vol. 3. CRC, Boca Raton, FL. 